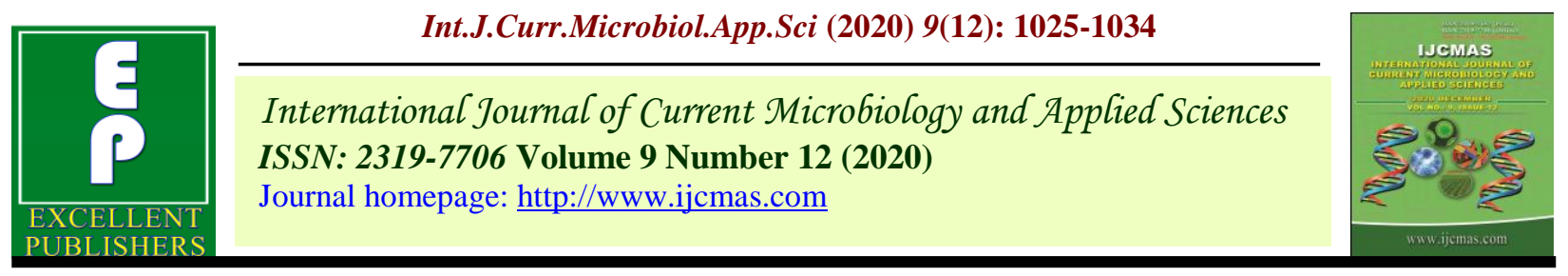

Review Article

https://doi.org/10.20546/ijcmas.2020.912.124

\title{
Wide Hybridization in Vegetable Crops
}

\author{
Pooja P. Gowda ${ }^{1 *}$, M. Rafeekher ${ }^{1}$ and K.R. Nithinkumar ${ }^{2}$ \\ ${ }^{1}$ College of Agriculture, Vellayani, Kerala, India \\ ${ }^{2}$ College of Horticulture, Bengaluru, Karnataka, India \\ *Corresponding author
}

K e y w o r d s
Wide hybridization,
Vegetable crops,
Green revolution
Article Info
Accepted:
10 November 2020
Available Online:
10 December 2020

Keywords

Wide hybridization,

Vegetable crops,

Green revolution

Article Info

Accepted:

10 November 2020

10 December 2020

\section{A B S T R A C T}

Green revolution has transformed India into a food grain surplus country from a deficit one. No other activity has such an immense impact on the agricultural development as the green revolution has done. It also, has reflected its impact on breeding and production of vegetable crops. Side effects of green revolution were witnessed largely in the form of reduced varietal diversity in major cultivated crop species and increased uniformity in appearance and harvestable products. This predisposed improved agriculture to natural calamities. Emergence of new pathogen races lead to outbreak of diseases and pest attack caused yield losses up to 50 percent. Changing climatic condition has caused abiotic stresses like drought, flood, salinity and high temperature, which in turn results in reduction of yield and quality. To feed the ever-increasing population and to fight with malnutrition, wild species offers the scope for quality improvement in vegetable cultivars.

\section{Introduction}

Green revolution has transformed India into a food grain surplus country from a deficit one. No other activity has such an immense impact on the agricultural development as the green revolution has done. It also, has reflected its impact on breeding and production of vegetable crops. Side effects of green revolution were witnessed largely in the form of reduced varietal diversity in major cultivated crop species and increased uniformity in appearance and harvestable products. This predisposed improved agriculture to natural calamities. Emergence of new pathogen races lead to outbreak of diseases and pest attack caused yield losses up to 50 percent. Changing climatic condition has caused abiotic stresses like drought, flood, salinity and high temperature, which in turn results in reduction of yield and quality. To feed the ever-increasing population and to 
fight with malnutrition, wild species offers the scope for quality improvement in vegetable cultivars.

In order to restore the characteristic of ecological sustainability and to combat the biotic and abiotic stress in cultivated vegetable crops, wide hybridization has been advocated a strong tool in the hand of plant breeders as wild species are the rich pool of noble characters, better quality and processing traits as well as imparting resistance against biotic and abiotic stress. Crop wild relatives have been used from decades for breeding, in particular to transfer genes of resistance or tolerance to pests, diseases or abiotic stress to the cultivated species. Wide hybridization comprises the efficient conventional breeding and modern molecular techniques as its effective tool in crop improvement (Table 18).

\section{Wide hybridization}

Wide hybridization as a norm is an attempt of intermating two species of a genus or two genera of a taxon with an intention of introgression of genes of economic value into the cultivated species. Wide hybridization invariably comprises crosses between wild, primitively cultivated species and genera. Interspecific hybridization means hybridization between individuals from different species belonging to same genus. Intergeneric hybridization means hybridization between individuals from different genus belonging to same family (Liu et al., 2014).

\section{Interspecific and Intergeneric hybridization}

\section{Role of wide hybridization}

Disease resistance against various pathogens
Insect resistance

Abiotic stress resistance

Quality improvement

Yield enhancement

Development of new crop species

Transfer of sterile cytoplasm for hybrids production

Rootstock breeding

Barriers associated with wide
hybridization

\section{Spatial isolation}

It is associated with geographical distance, physical separations of time and environment. Sensitivity to photoperiod, introduction to different latitudes and separation by geographical and political barriers can isolate two species reproductively. Development of different maturity groups in knol khol, radish and cauliflower are consequences of spatial isolation.

\section{Pre-fertilization barriers}

These barriers are operative between the parental species. They prevent crossability by hindering the fertilization process. Such disturbance of fertilization in interspecific crosses is also termed as interspecific incompatability or incongruity. Lack of pollen-stigma recognition is mainly responsible for incongruity. The reaction is sporophytic in nature and reported to be associated with pollen wall substances.

\section{Failure of pollen germination}

Interspecific hybrid in Cucumis species through conventional breeding procedures was unsuccessful because of the existence of a pre-fertilization barrier. The barrier was characterized by non-germination of pollen even up to 72 hours after pollination (Chatterjee and More, 1991). Kaneko and 
Bang (2014) reported the same problem in case of Brassica campestris and Raphanus sativus.

\section{Swollen pollen tube growth}

This has been widely reported in case of failure of wide crosses. Incompatibility in Cucumis spp. is characterized by delayed growth of pollen, or arrested pollen tube growth in the stigma, or inability of pollen tubes to reach the ovules (Chen and Adelberg, 2000). Based on pollen tube growth behaviour, crosses between African groups of Cucumis were classified into three groups, namely bilateral congruity, bilateral incongruity and unilateral incongruity.

\section{Lack of fertilization}

In such cases, pollen tube effectively delivered the two sperm nuclei to embryo sac. In one case, zygote was formed but no endosperm development while in second case 10 percent crosses developed endosperm but no embryo.

\section{Post fertilization barriers}

These barriers are operative in the distant hybrids and their progenies. These are also known as post syngamic barriers and include embryonic breakdown, failure of zygote development, abnormal fertilization, inhibition of endosperm and embryo development.

\section{Hybrid embryo abortion}

Arrest of embryo development or its abortion has been noticed in several interspecific hybrids. The major barriers to interspecific hybridization in Phaseolus sp. i.e. Phaseolus vulgaris $\times P$. acutifolius is embryo abortion. In case of Phaseolus coccineus $\times$ P. vulgaris, abnormal embryo development is observed (Andradf- Aguilar and Jackson, 1988).

\section{Hybrid inviability}

It results from various factors and manifests from zygote development to seed formation. It operates in $F_{1}$ seedlings causing high mortality, hybrid plants are characterized by poor growth, chlorotic leaves and die before maturity. The reason may be disharmony between nucleus of one species and cytoplasm of other or between nucleus of both the species or due to action of specific genes known to cause lethality, chlorosis and weakness in $\mathrm{F}_{1}$ hybrids. e.g. Cross between Cucumis sativus $\times$ C. melo and Abelmoschus esculentus $\times$ A. tetraphyllus.

\section{Hybrid sterility}

$F_{1}$ hybrids are characterized by lack of seed set. Hybrid sterility is due to manifestation of lethal genes, genetic imbalance due to chromosomal non-homology, chromosomal elimination and endosperm abortion. Several interspecific hybrids of Abelmoschus esculentus $\times$ A. ficulneus and Abelmoschus esculentus $\times$ A. tuberculatus show very poor seed set.

\section{Failure of flowering in the progenies}

Either hybrid is devoid of reproductive structure or highly deformed non-functional structures are formed. It is due to failure of physiological differentiation while nonfunctional reproductive systems are attributed to failure of meiosis in either one or both the sexes.

\section{Hybrid breakdown}

It is manifested in the form of inviable and weak $F_{2}$ generation or later generation. In some wide crosses seed setting is normal, even $F_{1}$ plant progenies show normal development and good fertility but in the $\mathrm{F}_{2}$ generation performance of hybrids fall below satisfaction and sometimes may be complete 
sterility. Afful et al., (2018) observed failure in fruit set, when the wild accessions were used as female parents in the crossability study of cultivated brinjal with Solanum torvum, S. anguvi and S. aethiopicum.

\section{Techniques to overcome pre-fertilization barriers}

\section{Taxonomic position of parental species}

An ease in hybridization is expected when the species more resemble phenotypically. Taxonomic classification is based on morphological features but by and large is the outcome of genetic factors in association with environment.

\section{Doubling of chromosome number}

When the failure of hybridization is due to different ploidy level then this technique is followed. In many polyploid cultivated species, their wild progenitors are diploid and crossing attempts are difficult. One may increase ploidy level of wild type by colchicine treatment. This enhances the success rate in crops like potato, Cucumis and Brassica spp.

\section{Bridging species technique}

In many crops, two species which are otherwise incompatible, may be hybridized with the help of third species. The third species acts as bridge in recombining the two incompatible species so known as bridging species. This technique has been used in making wide crosses in potato, lettuce and sugar beet.

Hayes et al., (2005) were successful in using S. verrucosum as a female bridging parent to access 2x (1EBN) S. pinnatisectum. Solanum simplicifolium was used as bridging species in crossing $S$. acuale and $S$. tuberosum

\section{Shortening of the style}

In some species, the incompatible reaction can be overcome by reducing the length of style. Incompatible reaction in radish can also be overcome by reduction of stylar tissues.

\section{Mentor pollination}

Pollen grains of distant species do not germinate on the stigma of cultivated species. However, when these pollen grains are mixed with killed maternal pollen grains, germination of the incompatible pollen grains take place as in case of Cucumis (Beharav and Cohen, 1994). It happens because cell wall proteins of pollen play pivotal role in pollen-pistil interaction. Pollen killed in ethanol and mixed with incompatible pollens, release the proteinaceous recognition factors, thereby masking rejection reaction of the recipient stigma. The killed maternal pollen is known as mentor pollen.

Use of growth regulators and immunosuppressants

Growth Regultors (GRs) enhance the zygotic formation in distant hybrids of many cucurbits, okra and tomato. Commonly used GRs are IAA, IBA, GA $3 . \mathrm{GA}_{3} 75 \mathrm{ppm}$ application to maternal plant 1 or 2 days before and after pollination improved zygote formation, faster pollen tube growth, more embryo survival and more seed set in wide crosses. Application of auxin in Solanum prevented flower abscission and enhanced fruit set.

\section{In vitro fertilization}

It is effective when stigma and style inhibit pollen tube growth and embryo abortion occurs at early stages of development. The whole gynoecium is excised and placed on MS medium followed by dusting of pollens on the stigma and fertilized ovule is reared to maturity (Ondrej et al., 2002). 


\section{Protoplast fusion}

It involves the fusion of protoplast of two incompatible species or genera and the fused heterokaryon is placed on artificial nutrient medium and regenerated into hybrid plant. This approach has particularly more potential to generate new genotypes in vegetatively propagating species. Some examples are tomato+potato, Solanum nigrum+ $S$. tuberosum. Chandel et al., 2015 studied interspecific potato somatic hybrids between cultivated $S$. tuberosum dihaploid C-13 and wild species $S$. cardiophyllum via protoplast fusion. The use of somatic fusion for improving valuable agronomic traits in cultivated potatoes is done for traits like atrazine resistance, frost tolerance, quality improvement and pest and diseases resistance.

\section{Techniques to overcome post-fertilization barriers}

\section{Embryo rescue}

Embryo abortion is the major barrier in distant hybridization. It can occur at any stage of development depending on the genomic relationship of two parental species. Solanum sitiens is a rare endemic plant of the Atacama Desert of Chile having tolerance to drought, salinity and low temperatures, resistances to certain pathogens, and modified fruit ripening. To overcome sterility and unilateral incompatibility of Solanum lycopersicum $\times S$. sitiens hybrids, embryo culture was used (Chetelat, 2016).

Capsicum chinense, $C$. annuum and $C$. frutescens were crossed with each other and embryo rescue was done between 27-33 days after pollination by Debbarama et al., 2013. Hybrid plants were obtained and their hybridity was confirmed using both morphological and RAPD markers.

\section{Ovary culture}

In some wide crosses, embryo abortion occurs at early stages of development when it is difficult to excise and culture embryos. To overcome this problem, ovaries are cultured. Depending on cross combination, ovaries 215 days after pollination are excised and cultured on nutrient medium. Flower is pruned by removing calyx, corolla and stamen. Distal part of the pedicel is cut and ovary planted on simple semi-solid MS nutrient medium. When the embryos become visible, they are aseptically taken out and cultured in a manner of embryo rescue technique

\section{Ovule culture}

Ovule culture is an elegant experimental system by which ovules are aseptically isolated from the ovary and are grown aseptically on chemically defined nutrient medium under controlled conditions. It is used when barrier impedes growth of zygote at earlier stages of development.

\section{Backcrossing}

Wide crosses showing poor fertility can be back crossed to cultivated species to improve the fertility of hybrids. Backcrossing can be applied to balance cytoplasmic interaction by producing cybrids or alloplasmic lines.

Chamola et al., 2015 used cytoplasmic male sterile (CMS) lines of Brassica juncea and B. napus with the mitochondrial genome of Moricandia arvensis and Erucastrum canariense, respectively, were used to transfer CMS to cauliflower (B. oleracea). Embryo rescue was also done in $\mathrm{BC} 1$ and $\mathrm{BC} 2$ to obtain progenies. Recovery of the recurrent parent phenotype was faster in $B$. napus x $B$. oleracea than $B$. juncea $\times$ B. oleracea. $\mathrm{BC} 3$ generation plants of $B$. napus $\times$ B . oleracea 
showed good curd formation and complete male sterility and nine bivalents at meiosis whereas those of $B$. juncea $\times$ B. oleracea were male sterile but still had genetic elements of B. juncea.

Table.1 Interspecific $v / s$ Intergeneric hybridization

\begin{tabular}{|l|l|l|}
\hline Particulars & Interspecific Hybridization & Intergeneric hybridization \\
\hline Parents involved & $\begin{array}{l}\text { Involve two different species of the } \\
\text { same genus }\end{array}$ & $\begin{array}{l}\text { Involve two different genera of } \\
\text { the same family }\end{array}$ \\
\hline $\begin{array}{l}\text { Fertility } \\
\text { Use in crop } \\
\text { improvement } \\
\text { fertile to completely sterile }\end{array}$ & Frequently used & Such hybrids always sterile \\
\hline $\begin{array}{l}\text { Release of hybrid } \\
\text { Varieties }\end{array}$ & Possible in some crops & less than interspecific crosses \\
\hline $\begin{array}{l}\text { Evolution of new } \\
\text { crops }\end{array}$ & $\begin{array}{l}\text { Not possible, but evolution of new } \\
\text { species is sometimes possible }\end{array}$ & Not possible \\
\hline
\end{tabular}

Table.2 Disease resistance in different vegetable crops

\begin{tabular}{|l|l|l|l|}
\hline Crop & Character transferred & Wild Species & Species \\
\hline Okra & Resistance to YVMV & Abelmoschus caillei & A. esculenta \\
\hline Brinjal & Bacterial wilt & S. stenotomum & S. melongena \\
\hline Tomato & Fusarium wilt & Solanum hirsutum & S. lycopersicum \\
\hline Chilli & Fruit rot & Capsicum chinense & C. annum \\
\hline Onion & Purple blotch & Allium fistulosum & A. cepa \\
\hline Potato & Late blight, leaf roll, virus-x & Solanum demissum & S. tuberosum \\
\hline French bean & Rust resistant & P. flavescens & P. vulgaris \\
\hline Cucumber & Green-mottle mosaic & Cucumis hardwickii & C. sativus \\
\hline
\end{tabular}

Table.3 Insect resistance in different vegetable crops

\begin{tabular}{|l|l|l|l|}
\hline Crop & Character transferred & $\begin{array}{l}\text { Species transferred } \\
\text { from }\end{array}$ & $\begin{array}{l}\text { Species transferred } \\
\text { to }\end{array}$ \\
\hline Tomato & White fly & Solanum hirsutum & S. esculentum \\
\hline & Root knot nematode & S. peruvianum & S. esculentum \\
\hline Potato & Nematode & S. vernei & S. tuberosum \\
\hline Okra & Fruit and shoot borer & A. manihot & A. esculentus \\
\hline Brinjal & Shoot and fruit borer & S. incanum & S. melongena \\
\hline & Epilachna beetle & S. nigrum & S. melongena \\
\hline Cucurbits & Fruit fly & Cucumis trigonus & C. sativus \\
\hline
\end{tabular}


Table.4 Abiotic stress resistance in different vegetable crops

\begin{tabular}{|l|l|l|l|}
\hline Crop & Character transferred & Species transferred from & Species transferred to \\
\hline Tomato & High temperature & Solanum cheesmani & S. lycopersicum \\
\hline Potato & Frost tolerance & Solanum acaule & S. tuberosum \\
\hline & Heat and drought & Solanum chacoense & S. tuberosum \\
\hline Onion & Tolerance to cold & Allium porrum & A. cepa \\
\hline Cucumber & Salinity & Benincasa hispida & Cucumis sativus \\
\hline Brassicae & Drought and heat & Brassica chinensis & B. oleraceae \\
\hline Okra & Low temperature & Abelmoschus angulosus & A. esculentus \\
\hline
\end{tabular}

Table.5 Quality improvement in different vegetable crops

\begin{tabular}{|l|l|l|l|}
\hline Crop & Character transferred & Species transferred from & $\begin{array}{l}\text { Species transferred } \\
\text { to }\end{array}$ \\
\hline Tomato & Carotenoid content & Solanum hirsutum & S. esculentum \\
\cline { 2 - 4 } Soluble solid & $\begin{array}{l}\text { Solanum chmielewskii } \\
\text { Thick rind and good keeping } \\
\text { quality }\end{array}$ & $\begin{array}{l}\text { Cucumismelovar. } \\
\text { cantaloupensis }\end{array}$ & C. melentum \\
\hline Potato & Starch content & Solanum acaule & S. tuberosum \\
\hline Chilli & High capsaicin & C. frutescence & C. annum \\
\hline Onion & Leaf flavour & Allium kurrat & A. cepa \\
\hline
\end{tabular}

Table.6 The use of somatic fusion for improving valuable agronomic traits in cultivated potatoes

\begin{tabular}{|c|c|}
\hline Trait & Fusion partner \\
\hline Atrazine resistance & S. tuberosum (+) S. nigrum \\
\hline Frost tolerance & S. tuberosum (+) S. commersonii \\
\hline Reduced glycoalkaloid aglycones & S. tuberosum (+) S. brevidens \\
\hline Resistance to bacterial wilt & S. tuberosum (+) S. phureja \\
\hline Resistance to late blight & $\begin{array}{l}\text { S. tuberosum (+) S. brevidens; } \\
\text { S. tuberosum (+) S. bulbocastanum }\end{array}$ \\
\hline $\begin{array}{l}\text { Resistance to potato leaf roll virus } \\
\text { (PLRV) }\end{array}$ & $\begin{array}{l}\text { S. tuberosum (+) S. brevidens; S. tuberosum (+) S. } \\
\text { verrucosum }\end{array}$ \\
\hline Resistance to potato virus Y (PVY) & S. tuberosum (+) S. brevidens \\
\hline
\end{tabular}


Table.7 Inter-specific hybridization in vegetable crops

\begin{tabular}{|c|c|c|c|}
\hline Tomato & Pusa Red Plum & S. lycopersicum $\times$ S. pimpinellifolium & Rich in Vit-C \\
\hline & Hissar Anmol & Hissar Arun x S. hirsutum f. glabratum & Resistant to TLCV \\
\hline Potato & Kufri Kuber & $\begin{array}{l}(\text { Solanum curtilobum } \times \text { S. tuberosum }) \times \\
\text { S. andigenum }\end{array}$ & High tuber yield \\
\hline Cucumber & C. hytivus & Cucumis sativus $\mathrm{x}$ C. hystrix & $\begin{array}{l}\text { Resistant to downy } \\
\text { mildew }\end{array}$ \\
\hline Amaranthus & Pusa Kiran & A. tricolour $\mathrm{x}$ A. tristis & Rainy season \\
\hline \multirow[t]{6}{*}{ Okra } & Pusa A4 & A. esculentus x A. manihot ssp. manihot & $\begin{array}{l}\text { Tolerant to jassids, Fruit } \\
\text { and shoot borer }\end{array}$ \\
\hline & Punjab-7 & $\begin{array}{l}\text { A. esculentus (Pusa Sawani) } \times \text { A. } \\
\text { manihot ssp. manihot (Ghana) }(2 n=194)\end{array}$ & \multirow[t]{4}{*}{ Resistance to YVMV } \\
\hline & Punjab Padmini & $\begin{array}{l}\text { A. esculentus (Rashmi) x A. manihot } \\
\text { ssp. manihot (Ghana) }\end{array}$ & \\
\hline & Parbhani Kranti & $\begin{array}{l}\text { A. esculentus (Pusa Sawani) } \mathrm{x} \text { A. } \\
\text { manihot }\end{array}$ & \\
\hline & Arka Anamika & \multirow{2}{*}{$\begin{array}{l}\text { A. esculentus }(2 n=130) \text { x A. tetraphyllus } \\
(2 \mathrm{n}=138) \\
\text { A. esculentus }(2 n=72) \text { x A. tetraphyllus } \\
(2 \mathrm{n}=130)\end{array}$} & \\
\hline & Arka Abhay & & $\begin{array}{l}\text { Resistance to YVMV } \\
\text { and tolerant to fruit } \\
\text { borer }\end{array}$ \\
\hline
\end{tabular}

Table.8 Inter-generic hybridization in vegetable crops

\begin{tabular}{|c|c|c|}
\hline New Crop & Parents & Special feature \\
\hline Hakurana & $\begin{array}{l}\text { Cabbage } \mathrm{x} \text { Chinese cabbage } \\
\text { (Developed by Embryo culture) }\end{array}$ & $\begin{array}{l}\text { New leafy vegetable } \\
\text { in Japan } \\
\text { Resistant to soft rot, } \\
\text { drought and heat }\end{array}$ \\
\hline Nabicol & Kale x Turnip & \\
\hline Caulicob & Cabbagex Cauliflower & \\
\hline Swede & Turnip x Cabbage & Root vegetable \\
\hline Raphanobrassica & Radish x Cabbage & Fodder crop \\
\hline $\begin{array}{l}\text { Baemoochae } \\
\text { (Brassicoraphanus) }(2 \mathrm{n}=38)\end{array}$ & $\begin{array}{l}B . \quad \text { rapa ssp. pekinensis (Big head } \\
\text { Chinese cabbage) x } R \text {. sativus (big root } \\
\text { radish) }\end{array}$ & New leafy vegetable \\
\hline
\end{tabular}

\section{Chromosome doubling}

Distant hybrids exhibit high degree of sterility, which is mainly due to genic or chromosomal difference between parental species. This problem in many cases has been overcome by doubling the chromosome number of $F_{1}$ hybrid. Bharathi et al., (2014) crossed natural tetraploid Momordica subangulata subsp. renigera $(2 \mathrm{n}=56)$ with induced tetraploid Momordica dioica $(2 \mathrm{n}=4 \mathrm{x}$ =56) to produce new species Momordica $\mathrm{x}$ suboica Bharathi. This hybrid maintains its morphological characteristics, superior agronomic traits making it a good choice as a new vegetable crop. 
In conclusion, wild species are the store house of novel genes, which can be utilized for wide hybridization. So, wild species forms the heart of wide hybridization programme. Wide hybridization is an effective tool for genetic improvement in vegetables crops. It is a highly technical and knowledge intensive process. Even though, wide hybridization has so many barriers, it can be overcome through the conventional and biotechnological approach. To broaden the genetic base, wide hybridization following in vitro and biotechnological approach is being used. It can be used for disease and insect resistance breeding and quality improvement in the cultivars, which is need of the hour.

\section{References}

Afful, N. T., Nyadanu, D., Akromah, R., Amoatey, H. M., Annor, C., and Diawouh, R. G. 2018.Evaluation of crossability studies between selected eggplant accessions with wild relatives S. torvum, $S$. anguivi and $S$. aethopicum. J. Plant BreedingCrop Sci. 10(1): 1-12.

Andradf- Aguilar, J. A. and Jackson, M. T. 1988. Attempts at Interspecific Hybridization Between Phaseolus vulgaris L. and $P$. acutifolius A. Gray- Using Embryo Rescue. Plant Breeding. 101(3): 173-180.

Beharav, A. and Cohen, Y. 1994. The crossability of Cucumis melo and Cucumis metuliferus, an investigation of in vivo pollen tube growth. Cucurbit Genet. Coop. Rep. 17:97-100.

Bharathi, L., Singh, H. S., and Kattukunnel, J. J. 2014. A novel synthetic species of Momordica (M. × suboica Bharathi) with potential as a new vegetable crop. Genet. Resources and Crop Evolution. 61(5):875-878.

Chamola, R., Balyan, H. S., and Bhat, S. 2015. Transfer of cytoplasmic male sterility from alloplasmic Brassica juncea and $B$. napus to cauliflower ( $B$. oleracea var. botrytis) through interspecific hybridization and embryo culture. Indian J. of Genetics and Plant Breeding. 73(2):203.

Chandel, P., Tiwari, J.K., and Ali, N. 2015. Interspecific potato somatic hybrids between Solanum tuberosum and Solanum cardiophyllum, potential source of late blight resistance breeding. Plant Cell Tiss Organ Cult. 123:579589.

Chatterjee, M. and More, T. A. 1991. Techniques to Overcome Barrier of Interspecific Hybridization in Cucumis. Cucurbit Genet. Coop. Rep., 14:66-68.

Chen, J. and Adelberg, J. 2000. Interspecific hybridization in Cucumis- Progress, problems and perspectives. HortSci. 35(1):11-15

Chetelat, T. R. 2016. Overcoming sterility and unilateral incompatibility of Solanum lycopersicum $\times S$. sitiens hybrids. Euphytica. 207(2): 1-4.

Debbarama, C., Khanna, V. K., Tyagi, W., Rai, M., and Meetei, N. T. 2013. Wide Hybridization and Embryo-Rescue for Crop Improvement in Capsicum. Agrotechnol.S11:003.

Hayes, R., Dinu, I. and Thill, C. 2005. Unilateral and bilateral hybridization barriers in inter series crosses of $4 \mathrm{x}$ 2EBN Solanum stoloniferum, $S$. pinnatisectum, S. cardiophyllum, and $2 \mathrm{x}$ 2EBN $S$. tuberosum haploids and haploid-species hybrids.Sex Plant Reprod., 17: 303.

Kaneko, Y. and Bang, S.W.2014. Interspecific and Intergeneric Hybridization and Chromosomal Engineering of Brassicaceae Crops. Breeding Sci., 64, 14-22.

Liu, D., Zhang, H., Zhang, L., Yuan, Z., Hao, M. and Zheng, Y. 2014. Distant hybridization Alien gene transfer in crop plants, vol 1 Springer, New York, 
Pp 25-42.

Ondrej, V., Navratilova, B., and Lebeda, A. 2002. Invitro cultivation of Cucumis sativus ovules after fertilization. Acta horticulturae, 1: 339-343.

\section{How to cite this article:}

Pooja P. Gowda, M. Rafeekher and Nithinkumar, K.R. 2020. Wide Hybridization in Vegetable Crops. Int.J.Curr.Microbiol.App.Sci. 9(12): 1025-1034.

doi: https://doi.org/10.20546/ijcmas.2020.912.124 